\title{
Proteinuria, Not Altered Albumin Metabolism, Affects Hyperlipidemia in the Nephrotic Rat
}

\author{
R. William Davies, llona Staprans,“ Florence N. Hutchison, and George A. Kaysen \\ Renal Biochemistry Laboratory, Division of Nephrology Department of Medicine, Veteran's Administration Medical Center, Martinez, \\ California 94553, Department of Medicine, University of California Davis School of Medicine at Davis, California, 94110; \\ *Department of Surgery, Veteran's Administration Medical Center, San Francisco, California 94121; \\ and University of California at San Francisco, San Francisco, California 94143
}

\begin{abstract}
It has been established previously that nephrotic hyperlipidemia is characterized by both an increase in lipid synthesis and a defect in removal of lipoproteins. The relationship between these defects and altered albumin metabolism is uncertain. One hypothesis is that hepatic lipogenesis increases in parallel with albumin synthesis. To test this hypothesis, albumin synthesis was increased in nephrotic rats fed an $8.5 \%$ protein diet (LPN) by increasing dietary protein to $40 \%$ (HPN). Proteinuria was modulated in half of the rats fed $40 \%$ protein by enalapril (HPE). Albumin synthesis was the same in both HPN and HPE, but proteinuria was reduced in HPE compared to HPN, and so were serum cholesterol and triglycerides (TG). To examine the effect of serum albumin on lipid clearance in the absence of proteinuria, plasma clearance of chylomicrons (CM) and VLDL was measured in Nagase analbuminemic rats (NAR) and found to be no different than in normal SD rats. When proteinuria was induced in NAR and in SD rats, a severe and identical defect in both $C M$ and VLDL clearance was acquired in both groups and blood lipid levels were increased to a similar degree in both groups. Neither hyperlipidemia nor defective removal of lipoproteins from the circulation are linked to albumin synthesis or serum albumin concentration but result, at least in part, from proteinuria. Postheparin lipoprotein lipase (LPL) activity was reduced slightly in nephrotic animals compared to nonnephrotic controls, but the most striking finding was a highly significant decrease in postheparin LPL activity in normal NAR compared to SD rats ( $P$ $<0.001$ ), suggesting that reduced LPL activity is not responsible for reduced clearance of CM and VLDL in nephrotic rats. (J. Clin. Invest. 1990. 86:500-505.) Key words: analbuminemia • nephrosis • chylomicrons • VLDL • lipoprotein lipase
\end{abstract}

\section{Introduction}

Hyperlipidemia and hypoproteinemia are hallmarks of the nephrotic syndrome. There is general agreement that the clear-

A portion of this work has been published in abstract form in 1989 . (Kidney Int. 35: 425a.)

Address reprint requests to Dr. Kaysen, Associate Chief of Staff of for Education 11/E, VA Medical Center, 150 Muir Road, Martinez, CA 94553.

Received for publication 27 June 1989 and in revised form 28 March 1990.

The Journal of Clinical Investigation, Inc.

Volume 86, August 1990, 600-605 ance of circulating lipids, specifically chylomicrons $(\mathrm{CM})^{1}(1$, 2) and VLDL is reduced (3) and hepatic synthesis of lipids and lipoproteins is increased $(4,5)$. The nephrotic syndrome results from altered glomerular permselectivity resulting in the urinary loss of macromolecules. As a consequence, serum albumin concentration and oncotic pressure $(\pi)$ are reduced. The relationship between disordered lipid metabolism and these other manifestations of the nephrotic syndrome has been a subject of controversy.

Two separate hypotheses have been proposed to establish a relationship between proteinuria and altered lipid metabolism. One postulate is that proteinuria causes reduced serum $\pi$, which in turn directly stimulates albumin synthesis. The rate of synthesis of all other liver-derived exported proteins, including lipoproteins, is proposed to be increased coordinately with that of albumin since all share a common secretory pathway (6-8). This model provides a mechanism for increased lipogenesis in nephrosis, but does not account for deranged lipid removal.

A second hypothesis, proposed by Staprans and Felts was that the urinary loss of a liporegulatory substance caused defective removal of lipids from the circulation. They identified a lipoprotein lipase (LPL) cofactor, heparan sulfate, lost in the urine in the nephrotic syndrome $(1,2)$.

The Nagase analbuminemic rat (NAR) is a strain of Sprague Dawley (SD) rat incapable of synthesizing albumin (9). Albumin is replaced by several larger liver-derived macroglobulins $(10,11)$. Serum protein concentration is normal (12), but serum $\pi$ is reduced. Although no urinary protein loss occurs in normal NAR, serum cholesterol and TG are increased (13-15). The NAR provides an opportunity to study lipoprotein clearance in animals that have no albumin yet have no defect in glomerular permselectivity. It is also possible to alter glomerular permselectivity in these animals and determine the effect of nonalbumin urinary protein loss on lipid metabolism.

Dietary protein augmentation increases both the rate of albumin synthesis (16) and impairs glomerular permselectivity (17) in SD rats with Heymann nephritis. Treatment with enalapril blunts the proteinuric effect of dietary protein augmentation, but not the stimulation of albumin synthesis (18). Thus it is possible to independently modulate albumin synthesis and

1. Abbreviations used in this paper: CM, chylomicrons; HPC, $40 \%$ protein diet control; HPCE, $40 \%$ protein control + enalapril; HPNE, high protein diet with enalapril; LPC, $8.5 \%$ protein diet control; LPCE, $8.5 \%$ protein control + enalapril; LPN, $8.5 \%$ protein diet nephrotic; LPNE, $8.5 \%$ protein nephrotic + enalapril; LPL, lipoprotein lipase; NAR, Nagase analbuminemic rat; SD, Sprague-Dawley; TG, triglycerides. 
glomerular permselectivity in nephrotic SD rats and determine whether an enhanced rate of albumin synthesis would increase blood lipid levels independent of changes in proteinuria.

We report here the relationship between albumin synthesis and blood lipid levels in both nephrotic and normal SD rats as well as the metabolic clearance of both CM and VLDL in normal and nephrotic NAR and SD rats.

\section{Methods}

Four separate experimental protocols were performed. In the first protocol CM clearance was compared in normal NAR and SD rats to determine whether the clearance of CM was altered by the absence of serum albumin. Proteinuria was then produced in both SD and NAR rats to determine whether $\mathrm{CM}$ clearance became abnormal after an alteration in glomerular permselectivity.

In protocol 2, VLDL clearance was measured in nephrotic and normal NAR and SD rats as in protocol 1 . Postheparin LPL activity was then measured in the same animals.

In the third and fourth protocols the relationship between blood lipids and albumin synthesis was evaluated utilizing SD rats with experimental nephrotic syndrome (passive Heymann nephritis) (protocol 3) and normal SD rats (protocol 4). Albumin synthesis was increased by dietary protein augmentation from 8.5 to $40 \%$ in both the nonnephrotic and nephrotic groups and the angiotensin-converting enzyme inhibitor enalapril, was used to modulate proteinuria in protocol 3.

Protocol 1: The effect of analbuminemia and proteinuria on CM clearance. 14 male SD and 13 male NAR rats weighing between 350 and $400 \mathrm{~g}$ were maintained on standard Purina Rat Chow with free access to food and water in a 12-h light cycle. Two groups of rats (eight SD and seven NAR) were injected intraperitoneally with the sheep antiserum FX1A (courtesy of Dr. William Couser, University of Washington, Seattle, WA) to induce passive Heymann nephritis. The remaining rats (six SD and six NAR) were not injected with antiserum and served as controls.

$15 \mathrm{~d}$ after injection with antiserum, each animal was placed in a metabolic cage for 24-h urine collection to measure total protein, albumin $(66 \mathrm{kD})$, transferrin $(76 \mathrm{kD})$, and the concentration of the 44-kD glycoprotein $\alpha_{1}$-acid glycoprotein ( $\alpha_{1}$-AG). Transferrin and $\alpha_{1}$-AG were used to quantitatively compare defects in glomerular permselectivity in the two groups, since no albumin is present in the urine of the analbuminemic rat.

Measurement of plasma CM clearance. Labeled CM were obtained from a thoracic duct cannula by a modification of the technique of Bollman (19) as previously described (2). Between 9:00 a.m. and 12:00 noon, after an overnight fast, $0.5 \mathrm{c}^{3}$ of ${ }^{3} \mathrm{H}$-labeled $\mathrm{CM}$ ( $10 \mathrm{mg}$ triglyceride, TG) were injected into a tail vein of each experimental animal without anesthesia for measurement of CM removal from whole blood. Blood samples were obtained from a tail vein at intervals of 2,4 , $6,8,10,12,15$, and $20 \mathrm{~min}$ after injection. Lipids were then extracted from each blood sample by the Dole method, as modified by Trout (20). Extracted samples were counted in a scintillation counter (Beckman instruments, Inc., Fullerton, CA) for $10 \mathrm{~min}$. Individual $\mathrm{CM}$ clearance curves were calculated from the slopes of serum counts/minute using the method of least squares. The rate constant for CM clearance was determined for each animal as $\ln 2 / T_{1 / 2}$. A mean CM disappearance curve was determined for each group of animals by regression analysis using the means of each time point (based on percent remaining counts) from all animals within each group.

At the end of the clearance study all animals were anesthetized with sodium pentobarbital $(20 \mathrm{mg} / \mathrm{kg})$ and exsanguinated by aortic puncture for measurement of serum proteins and lipids.

Protocol 2: The effect of analbuminemia and proteinuria on VLDL clearance and postheparin LPL activity. Nine male SD and nine male NAR rats weighing between 307 and $352 \mathrm{~g}$ were maintained on standard Purina Rat Chow with free access to food and water in a 12-h light cycle. Two groups of rats (five SD and four NAR) were rendered nephrotic as in protocol 1 while the remaining rats (four SD and five NAR) served as controls.

Measurement of plasma VLDL clearance. Labeled VLDL was prepared by the method of Bar-on et al. (21) using $\left[{ }^{3} \mathrm{H}\right]$ glycerol. VLDL was isolated by the method of Havel et. al. (22). $0.6 \mu \mathrm{Ci}$ of VLDL was injected into a tail vein of each experimental animal without anesthesia for measurement of VLDL removal from whole blood. Samples and calculations were treated the same as for $\mathrm{CM}$ clearance described above.

Measurement of postheparin LPL activity. At the end of measurement of VLDL clearance, animals were allowed free access to food and water for $\mathbf{4 8} \mathrm{h}$. They were then anesthetized with sodium pentobarbi$\mathrm{tal}$, the abdomen was incised and heparin $(10 \mathrm{U} / \mathrm{kg})$ was injected into the right femoral vein. Rats were exsanguinated 5 min later from the abdominal aorta for measurement of postheparin LPL. LPL activity was then assayed by measurement of hydrolysis of intralipid (23).

$1 \mathrm{ml}$ reaction mixtures consisted of: $0.1 \mathrm{ml}$ of $1.3 \mathrm{M}$ Tris- $\mathrm{HCl}, \mathrm{pH}$ 8.6; $0.1 \mathrm{ml}$ of $0.025 \mathrm{M} \mathrm{NH}_{4} \mathrm{OH}, \mathrm{pH} 8.6 ; 0.3 \mathrm{ml}$ of $15 \%$ (wt/vol) crystalline bovine serum albumin (Sigma Chemical Co., St. Louis, MO), $0.1 \mathrm{ml}$ of $10 \%$ Intralipid (Vitrum, Stockholm, Sweden), $0.2 \mathrm{ml}$ normal rat serum, and $0.2 \mathrm{ml}$ of postheparin plasma. Duplicate samples were incubated for $60 \mathrm{~min}$ at $37^{\circ} \mathrm{C}$. Free fatty acids (FFA) were extracted and their content was determined by titration with tetrabutyl ammonium hydroxide. Reaction mixtures lacking postheparin plasma were incubated under the same conditions to serve as control blanks. LPL activity was defined in units as micromoles of FFA released/ hour/milliliter of postheparin plasma. When incubation was carried out in the presence of $1 \mathrm{M} \mathrm{NaCl}$, no release of FFA was detected, indicating that this method specifically determined LPL and not hepatic triacylglycerol lipase.

Protocol 3: Relationship between albumin synthesis and blood lipid levels in nephrotic SD rats. 40 male SD rats weighing $120-150 \mathrm{~g}$ were injected intraperitoneally with sheep FX1A antiserum and then fed an 8.5\% protein diet (Purina diet 5769 [8.5\% casein], Ralston Purina, Richmond, IN) for a period of $11 \mathrm{ds,} \mathrm{after} \mathrm{which} \mathrm{dietary} \mathrm{protein} \mathrm{intake}$ was increased to $40 \%$ in 19 rats (Purina protein diet 5779 [40\% casein]). The remaining animals were continued on the $8.5 \%$ protein diet. The two diets were isocaloric, containing identical amounts of fat and minerals, differing only in the proportion of calories provided either as carbohydrate or as protein. Seven animals in the high protein group (HPNE) had enalapril added to their drinking water $(40 \mathrm{mg} / \mathrm{kg}$ per d) at the same time that dietary protein intake was increased to blunt the increase in proteinuria anticipated to result from the increased dietary protein intake (17). The animals that were switched to the $40 \%$ protein diet and not treated with enalapril are referred to as HPN (12 animals). Enalapril was added to the drinking water of seven animals maintained on the $8.5 \%$ protein diet (LPNE). The remaining animals maintained on the $8.5 \%$ protein diet are referred to as LPN (14 animals). $4 \mathrm{~d}$ later ( $15 \mathrm{~d}$ after injection with antiserum) albumin turnover rate (synthesis) was measured as previously described $(16,18)$.

Protocol 4: Relationship between albumin synthesis and blood lipids in normal SD rats. 26 rats were fed $8.5 \%$ protein as above for a period of $11 \mathrm{~d}$, after which dietary protein intake was increased to $40 \%$ in 13 rats. The remaining animals were continued on $8.5 \%$ protein. Four rats fed $40 \%$ protein were treated with enalapril (HPCE) to determine whether enalapril exerted any effect on blood lipid levels in animals without significant proteinuria, while nine remained untreated (HPC). Five animals fed $8.5 \%$ protein were treated with enalapril (LPCE) and eight remained untreated (LPC). Albumin turnover studies were initiated $4 \mathrm{~d}$ after the increase in dietary protein as described previously $(16,18)$.

Chemical determinations. Measurements of serum and urine albumin, transferrin and $\alpha_{1}$ AG were performed utilizing electroimmunodiffusion (24) as described previously (25). Total protein was measured in serum using the method of Lowry (26). Cholesterol and TG measurements were performed utilizing a quantitative, enzymatic method (procedures 352 and 338, respectively, Sigma Diagnostics, St. Louis, 
MO) (27-29). Serum $\pi$ was kindly measured for us by Dr. Eugene Renkin using an oncometer with a PM 30 Amicon membrane (30).

Statistics. All values were analyzed by the omega statistic to determine whether variables were normally distributed. When variables were normally distributed comparisons were performed using a oneway analysis of variance (31). The Kruskal-Wallis analysis of variance by ranks was used to compare non-normally distributed values. A $P$ value of $<0.05$ was considered to be statistically significant. Figs. 1 and 2 are disappearance curves for chylomicrons and VLDL, respectively. Statistical differences between chylomicron or VLDL metabolism were determined using rate constants rather than $t_{1 / 2}$ values since the latter are not normally distributed. Multiple regression analysis was performed using Microstat, an interactive program that generates a table of partial correlation coefficients and then analyzes these by a stepwise regression procedure.

\section{Results}

The clearance of CM and VLDL from plasma was the same in normal NAR and normal SD rats even though albumin was virtually absent from the serum of normal NAR (Figs. 1 and 2, Tables I and II). Serum cholesterol however, was increased significantly in the normal NAR (Table I and II) when compared to normal SD. Serum TG concentration also tended to be greater in the NAR (Table I). When proteinuria was induced serum cholesterol and TG concentrations increased significantly in both nephrotic SD and NAR (Table I and II). This increase in blood lipids was accompanied by a large and significant decrease in the clearance of CM and VLDL (Tables I and II, Figs. 1 and 2). As in nonnephrotic animals, CM and VLDL clearance was the same in both groups of nephrotic rats even though albumin was absent from the serum of nephrotic NAR and was present in nephrotic SD.

Postheparin LPL activity was reduced slightly in nephrotic animals compared to nonnephrotic controls, but the most striking finding was a highly significant decrease in postheparin LPL activity in normal NAR when compared to normal SD rats (Table II).

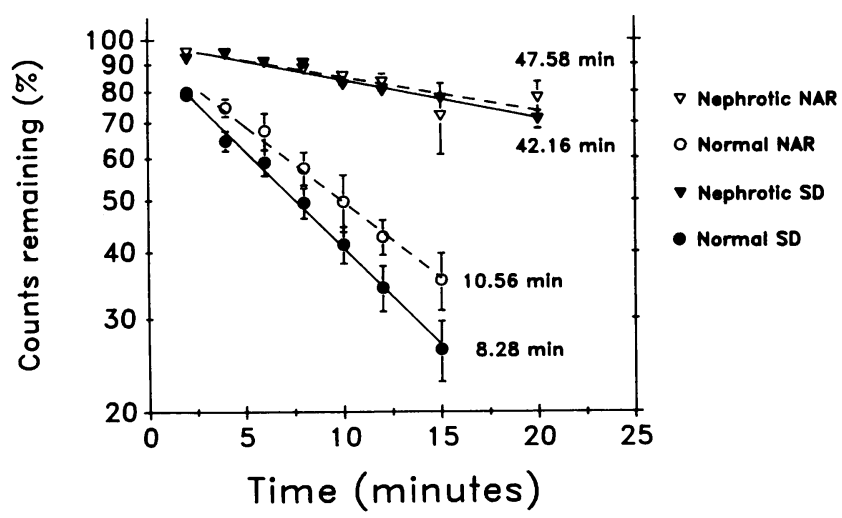

Figure 1. Chylomicron clearance in normal and nephrotic SpragueDawley and Nagase analbuminemic rats. Each data point represents the mean value for percent counts remaining compared to counts extrapolated at zero time. Error bars conote SEM. Time represents time since injection of ${ }^{3} \mathrm{H}$-lipoprotein. Chylomicron clearance was measured by the disappearance of ${ }^{3} \mathrm{H}$-labeled chylomicrons after intravenous injection. NAR is represented by open symbols and broken lines, $\mathrm{SD}$ is represented by solid symbols and lines. Nephrotic rats are represented by inverted triangles and nonnephrotic rats by circles. Normal SD, $n=6$. Normal NAR, $n=6$. Nephrotic SD, $n$ $=8$. Nephrotic NAR, $n=7$.

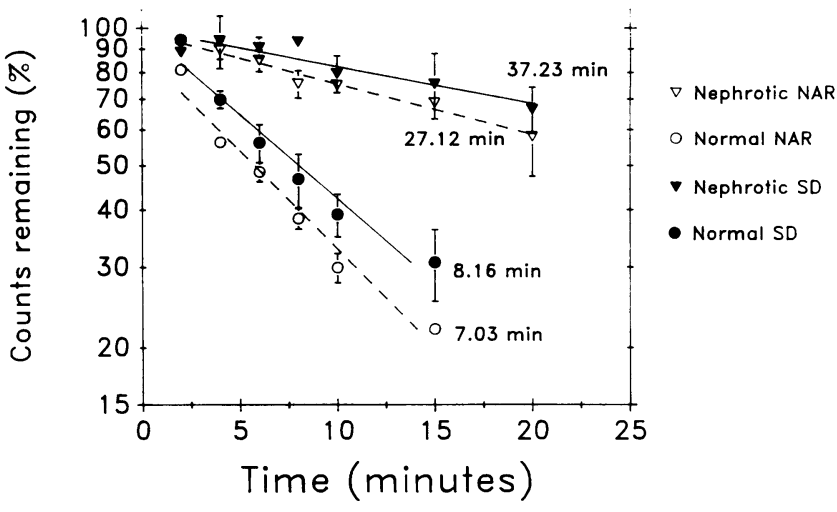

Figure 2. VLDL clearance in normal and nephrotic SD and NAR. Each data point represents the mean value for percent counts remaining compared to counts extrapolated at zero time. Error bars conote SEM. Time represents time since injection of ${ }^{3} \mathrm{H}$-lipoprotein. VLDL clearance was measured by the disappearance of ${ }^{3} \mathrm{H}$-labeled VLDL after intravenous injection. Symbols are the same as in Fig. 1. Normal SD, $n=3$. Normal NAR, $n=2$. Nephrotic SD, $n=3$. Nephrotic NAR, $n=3$.

Serum $\pi$ was significantly greater in normal SD than in normal NAR (protocol 1, Table I, $P<0.05$ ), but was similar in both groups of nephrotic animals. Serum TG correlated with $\mathrm{CM}$ clearance by multiple regression analysis, while serum cholesterol did not. Serum cholesterol concentration correlated negatively with serum $\pi$, while serum TG did not.

A $40 \%$ protein diet increased albuminuria, renal albumin clearance, and the rate of albumin synthesis in nephrotic rats (HPN), and both serum cholesterol and TG concentrations were greater in these animals when compared to LPN (Table III). Enalapril limited the increase in both albuminuria and the renal clearance of albumin, yet the rate of albumin synthesis was no different in HPNE and HPN. Both serum cholesterol and TG were significantly less in HPNE than in HPN although albumin synthesis rate was the same in these two groups. LPN had the lowest rate of albumin synthesis, the least albuminuria and the lowest renal clearance of albumin among the nephrotic animals, yet blood lipids were intermediate between HPN and HPNE.

The rate of albumin synthesis was significantly greater in HPC than in LPC and in HPCE than in LPCE $(P<0.05$, Table III), yet blood lipids were no different between these four groups. Thus alterations in albumin synthesis caused by changes in dietary protein cause no change in blood lipid levels in either normal or nephrotic rats.

\section{Discussion}

Since the rate of removal of CM and VLDL from the circulation is the same in normal NAR and SD rats, despite the complete absence of albumin from the serum of NAR, albumin is clearly not required for a normal rate of CM or VLDL removal. The finding that CM and VLDL clearance became equally abnormal in nephrotic SD and NAR following the development of proteinuria implies that the urinary loss of a substance other than albumin is necessary for the development of delayed CM and VLDL clearance in the nephrotic syndrome. The presence of albumin in the nephrotic SD rat did not lead to a lesser defect in CM or VLDL removal in these animals. The defect in CM and VLDL clearance in the ne- 
Table I. Serum Protein and Lipid Metabolism in Normal and Nephrotic Sprague-Dawley and Nagase Analbuminemic Rats

\begin{tabular}{|c|c|c|c|c|c|c|c|c|c|c|c|c|c|c|c|c|}
\hline \multirow[b]{2}{*}{ Group } & \multirow[b]{2}{*}{ Weight } & \multirow{2}{*}{$\begin{array}{l}\text { Chylo rate } \\
\text { constant }\end{array}$} & \multicolumn{7}{|c|}{ Serum } & \multicolumn{4}{|c|}{ Urine } & \multicolumn{3}{|c|}{ Renal clearance } \\
\hline & & & Prot & Alb & Chol & TG & Trans & $\alpha_{1} \mathrm{AG}$ & $\pi$ & Albumin & Trans & $\alpha 1-\mathrm{AG}$ & Protein & Albumin & Trans & $\alpha_{1} \mathrm{AG}$ \\
\hline$n$ & $g$ & & $\mathrm{mg} / \mathrm{ml}$ & $m g / m l$ & \multicolumn{2}{|c|}{$m g / d l$} & $\mathrm{mg} / \mathrm{ml}$ & $m g / m l$ & $\mathrm{mmHg}$ & & & \multicolumn{2}{|c|}{$m g / 24 h$} & \multicolumn{3}{|c|}{$\mathrm{ml} / \mathrm{min} \times 10^{-3}$} \\
\hline SDC & 376.9 & 0.0961 & 62.7 & 30.9 & 97.8 & 176.0 & 7.7 & 3.0 & 21.6 & & & & & & & \\
\hline (6) & \pm 14.5 & $\pm 0.0173^{*}$ & \pm 3.0 & \pm 1.7 & $\pm 6.2^{* \ddagger}$ & $\pm 39.1^{*}$ & $\pm 1.3^{* \neq}$ & $\pm 0.2^{*}$ & $\pm 1.6^{\S}$ & & & & & & & \\
\hline NARC & 383.0 & 0.0726 & 60.6 & - & 244.3 & 274.5 & 14.64 & 2.8 & 16.4 & & & & & & & \\
\hline (6) & \pm 26.8 & $\pm 0.0091^{*}$ & \pm 2.4 & & $\pm 25.1^{*}$ & $\pm 58.2^{*}$ & $\pm 0.2^{* \|}$ & $\pm 0.3^{*}$ & $\pm 1.0^{*}$ & & & & & & & \\
\hline SDN & 376.9 & 0.0137 & 53.1 & 8.1 & 404.1 & 1,457 & 1.3 & 0.6 & 9.4 & 571.8 & 160.7 & 45.7 & $1,163.1$ & 67.7 & 95.0 & 62.2 \\
\hline (8) & \pm 11.0 & $\pm 0.0020^{\prime \prime}$ & $\pm 1.13^{\| \prime}$ & $\pm 1.7^{\prime \prime}$ & $\pm 37.2^{\prime \prime}$ & $\pm 498^{\prime \prime}$ & $\pm 0.2^{* \|}$ & $\pm 0.1^{\prime \prime}$ & $\pm 0.4^{\prime \prime}$ & \pm 59.8 & \pm 15.9 & $\pm 3.3^{*}$ & $\pm 52.1^{*}$ & \pm 16.1 & $\pm 13.4^{*}$ & \pm 12.3 \\
\hline NARN & 349.1 & 0.0149 & 55.9 & - & 473.3 & 939 & 3.0 & 0.6 & 10.8 & - & 163.7 & 24.3 & 557.1 & - & 40.5 & 40.9 \\
\hline (7) & \pm 13.8 & $\pm 0.0033^{\ddagger}$ & \pm 3.0 & & \pm 38.2 & $\pm 128^{\prime \prime}$ & $\pm 0.5^{\prime \prime}$ & $\pm 0.1^{11}$ & $\pm 0.1^{\prime \prime}$ & & \pm 28.4 & \pm 4.6 & \pm 119.3 & & \pm 6.7 & \pm 6.7 \\
\hline
\end{tabular}

Values are means \pm SEM. ${ }^{*} P<0.01$ vs. NARN. ${ }^{\ddagger} P<0.01$ vs. NARC. ${ }^{\S} P<0.05$ vs. NARC. $" P<0.01$ vs. SDC. SDC, Sprague-Dawley control; NARC, Nagase analbuminemic rat-control; SDN, Sprague-Dawley nephrotic; NARN, Nagase analbuminemic rat-nephrotic; Chylo rate constant, chylomicron rate constant, $\ln 2 / T_{1 / 2}$; Prot, serum protein; Alb, serum albumin; Chol, cholesterol; TG, triglycerides; Trans, serum transferrin; $\alpha_{1}$-AG, serum $\alpha_{1}$ acid glycoprotein; $\pi$, serum oncotic pressure. Urine from nonnephrotic rats was not assayed for proteins. Chylomicron clearance was measured by the disappearance of ${ }^{3} \mathrm{H}$-labeled chylomicrons after intravenous injection.

phrotic syndrome is therefore not caused by alterations in serum albumin concentration, but instead results from deranged glomerular permselectivity; presumably from the urinary loss of a substance(s) necessary for normal lipid clearance.

The finding that postheparin LPL activity was greatly reduced in normal NAR compared to normal SD, while LPL activity was only slightly decreased in nephrotic animals compared to nonnephrotic controls was unexpected. The initial clearance of both CM and VLDL are therefore quantitatively unrelated to postheparin LPL activity. One must postulate a derangement in the initial step in the metabolism of both VLDL and CM before hydrolysis by LPL in the nephrotic syndrome. The defect may be in their binding to the vascular endothelium.

The observation that dietary protein modulates albumin synthesis without effecting a change in blood lipid levels in normal rats strongly suggests that albumin synthesis is unre- lated to lipid metabolism. Furthermore, the observation that blood lipid levels were increased only slightly and not significantly in nephrotic HPNE compared to the nonnephrotic LPC animals although the rate of albumin synthesis was nearly threefold higher in HPNE, again provides strong evidence that albumin synthesis is not causally linked to increased blood lipid levels.

While proteinuria was less in HPNE than in HPN, proteinuria was significantly greater in HPNE than in LPN, yet plasma TG concentration was significantly greater and cholesterol concentration tended to be greater in LPN. One reason for the greater blood lipid levels in LPN may rest in the fact that this group was consuming a high carbohydrate diet, a diet that would be expected to increase serum TG concentration. It is also possible that a higher serum $\pi$ in HPNE, compared to LPN, may have contributed to normalizing blood lipid levels in HPNE.

Table II. Comparison of Blood Lipids and Serum and Urine Proteins in Normal and Nephrotic Sprague-Dawley and Nagase Analbuminemic Rats

\begin{tabular}{|c|c|c|c|c|c|c|c|c|c|c|c|c|}
\hline \multirow[b]{2}{*}{ Group } & \multirow[b]{2}{*}{ Weight } & \multirow{2}{*}{$\begin{array}{l}\text { VLDL rate } \\
\text { constant }\end{array}$} & \multicolumn{5}{|c|}{ Serum } & \multicolumn{3}{|c|}{ Urine } & \multicolumn{2}{|c|}{ Renal clearance } \\
\hline & & & Alb & Chol & TG & Trans & PHLPL & Albumin & Trans & Protein & Albumin & Trans \\
\hline$n$ & $g$ & & $m g / m l$ & $m g / d l$ & \multicolumn{2}{|c|}{$m g / m l$} & $\mu m F F A / m l / h$ & \multicolumn{3}{|c|}{$m g / 24 h$} & \multicolumn{2}{|c|}{$\mathrm{ml} / \mathrm{min} \times 10^{-3}$} \\
\hline SDC & 312.6 & 0.0875 & 38.7 & 75.2 & 127.8 & 4.1 & 3.7 & & & & & \\
\hline (4) & \pm 5.4 & \pm 0.0120 & \pm 1.6 & $\pm 7.0^{*}$ & \pm 20.1 & $\pm 0.3^{*}$ & $\pm 0.5^{\ddagger}$ & & & & & \\
\hline NARC & 341.4 & 0.1007 & - & 259.0 & 139.0 & 5.0 & 0.8 & & & & & \\
\hline (5) & \pm 6.0 & \pm 0.0089 & & $\pm 59.1^{\S}$ & $\pm 24.5^{\S}$ & $\pm 0.8^{\S}$ & \pm 0.3 & & & & & \\
\hline SDN & 325.4 & 0.0120 & 16.5 & 439.4 & 986.6 & 1.9 & 2.1 & 570.1 & 58.6 & 632 & 28.8 & 21.8 \\
\hline (5) & \pm 11.9 & $\pm 0.0061^{\prime \prime}$ & $\pm 2.5^{\prime \prime}$ & $\pm 82.9^{\prime \prime}$ & $\pm 269.4^{\prime \prime}$ & $\pm 0.3^{\delta \| !}$ & \pm 0.7 & \pm 78.1 & \pm 7.8 & \pm 81 & \pm 8.1 & $\pm 6.0^{\S}$ \\
\hline NARN & 330.3 & 0.0245 & - & 641.3 & 305.0 & 1.7 & 0.5 & - & 53.9 & 721 & - & 26.1 \\
\hline$(5)$ & \pm 5.7 & $\pm 0.0044^{*}$ & & \pm 48.2 & \pm 51.3 & \pm 0.4 & \pm 0.3 & & \pm 8.7 & \pm 68 & & \pm 1.7 \\
\hline
\end{tabular}

Values are means \pm SEM. ${ }^{*} P<0.01$ vs. NARC. ${ }^{\ddagger} P<0.001$ vs. NARC. ${ }^{\S} P<0.01$ vs. NARN. $" P<0.01$ vs. SDC. PHLPL activity, Postheparin lipoprotein lipase activity. SDC, Sprague-Dawley control. NARC, Nagase analbuminemic rat-control. SDN, Sprague-Dawley nephrotic. NARN, Nagase analbuminemic rat-nephrotic. VLDL rate constant, very low density lipoprotein rate constant, $\ln 2 / T_{1 / 2}$. Alb, albumin; Chol, cholesterol; TG, triglycerides; Trans, transferrin. Urine studies were not performed on the nonnephrotic control rats. VLDL clearance was measured by the disappearance of ${ }^{3} \mathrm{H}$-labeled VLDL after intravenous injection. 
Table III. Effect of Dietary Protein Content and Enalapril on Albumin Synthesis and Blood Lipid Levels in Normal and Nephrotic Sprague-Dawley Rats

\begin{tabular}{|c|c|c|c|c|c|c|c|}
\hline Group & Weight & $\begin{array}{l}\text { Albumin } \\
\text { synthesis }\end{array}$ & Chol & TG & $\begin{array}{l}\text { Serum } \\
\text { albumin }\end{array}$ & $\begin{array}{c}\text { Clearance } \\
\text { albumin }\end{array}$ & Urine albumin \\
\hline$n$ & $g$ & $m g / h$ per $100 \mathrm{~g}$ & $m g / d l$ & $m g / d l$ & $m g / m l$ & $\mathrm{ml} / \mathrm{min} \times 10^{-3}$ & $m g / h$ per $100 \mathrm{gBW}$ \\
\hline \multicolumn{8}{|c|}{ Nephrotic Sprague-Dawley rats (protocol 3) } \\
\hline LPN & 175.1 & 9.1 & 188.6 & 304.6 & 13.6 & 6.1 & 2.5 \\
\hline (14) & \pm 6.6 & $\pm 0.6^{* \ddagger}$ & $\pm 18.1^{*}$ & $\pm 94.4^{\ddagger}$ & $\pm 1.0^{\prime \prime}$ & $\pm 0.8^{* \ddagger}$ & $\pm 0.3^{* \ddagger}$ \\
\hline LPNE & 172.8 & 9.1 & 211.7 & 232.1 & 10.9 & 9.4 & 3.2 \\
\hline (7) & \pm 14.9 & \pm 0.9 & \pm 17.5 & \pm 87.3 & \pm 1.9 & \pm 2.4 & \pm 0.4 \\
\hline HPN & 175.6 & 18.8 & 343.2 & 425.4 & 12.7 & 33.2 & 12.1 \\
\hline$(12)$ & \pm 7.0 & \pm 1.2 & \pm 49.8 & \pm 173.8 & \pm 1.4 & \pm 4.95 & \pm 0.9 \\
\hline HPNE & 187.4 & 15.6 & 157.1 & 111.5 & 17.8 & 12.5 & 6.5 \\
\hline (7) & \pm 14.1 & \pm 2.5 & $\pm 26.0^{*}$ & $\pm 10.0^{\S}$ & $\pm 2.1^{*}$ & $\pm 3.3^{*}$ & $\pm 1.2^{*}$ \\
\hline \multicolumn{8}{|c|}{ Normal Sprague-Dawley rats (protocol 4) } \\
\hline HPC & 233.5 & 9.2 & 87.7 & 133.3 & 44.4 & - & - \\
\hline (9) & \pm 8.2 & \pm 0.9 & \pm 6.5 & \pm 28.3 & \pm 1.1 & & \\
\hline HPCE & 245.4 & 11.1 & 90.1 & 89.5 & 41.0 & - & - \\
\hline (4) & \pm 9.0 & \pm 0.3 & \pm 5.9 & \pm 21.6 & \pm 0.6 & & \\
\hline LPC & 233.9 & 6.4 & 92.0 & 105.9 & 37.7 & - & - \\
\hline (8) & \pm 8.9 & $\pm 0.9^{\prime \prime}$ & \pm 5.3 & \pm 14.2 & $\pm 0.6^{\prime \prime}$ & & \\
\hline LPCE & 248.8 & 8.4 & 87.7 & 152.4 & 29.7 & - & - \\
\hline (5) & \pm 4.2 & \pm 0.6 & \pm 4.3 & \pm 21.9 & $\pm 0.9^{\prime \prime}$ & & \\
\hline
\end{tabular}

Values are mean \pm SEM. ${ }^{*} P<0.02$ vs. HPN. ${ }^{\ddagger} P<0.02$ vs. HPNE. ${ }^{\S} P<0.05$ vs. HPN. $" P<0.05$ vs. HPC. HPN, $40 \%$ protein diet nephrotic; HPNE, $40 \%$ protein diet nephrotic + enalapril $(40 \mathrm{mg} / \mathrm{kg}$ per d). LPN, $8.5 \%$ protein diet nephrotic; LPNE, $8.5 \%$ protein nephrotic + enalapril; HPC, $40 \%$ protein diet control; HPCE, $40 \%$ protein control + enalapril; LPC, $8.5 \%$ protein diet control; LPCE, $8.5 \%$ protein control + enalapril; Chol, cholesterol; TG, triglycerides; Clearance, renal albumin clearance. Albumin turnover was measured using ${ }^{125}$ I-labeled albumin, which at steady state is equal to albumin synthesis.

Within the nephrotic SD group, dietary protein augmentation resulted in increased blood lipid levels only when the renal clearance of albumin increased and serum albumin concentration did not. The effect of dietary protein supplementation on the rate of albumin synthesis was not predictive of its effect on blood lipid levels. While these observations do not exclude an independent effect of serum $\pi$ on the modulation of blood lipid levels in nephrotic animals, we show that increased blood lipids occur without a parallel increase in the synthesis of the most abundant secretory protein, albumin. The observation that infusion of dextran, a nonalbumin oncotically active substance, reduces blood lipid levels in NAR (32) as well as in nephrotic animals (33) strongly suggests that reduction in serum $\pi$, and not specifically the absence of albumin from the serum is responsible for a component of hypoalbuminemia both in nonnephrotic NAR and in the nephrotic syndrome. Furthermore, the observation that CM and VLDL are cleared normally from the blood of nonnephrotic NAR excludes a relationship between serum albumin and this aspect of hyperlipidemia as well.

The normal NAR exhibits an increase in both serum cholesterol and TG, most likely resulting from increased synthesis of lipids (15) rather than from their defective removal. The negative correlation between serum cholesterol and serum $\pi$ (protocol 1) both in these animals and as previously reported by this laboratory in nephrotic patients (34) suggests that reduced serum $\pi$ in some way stimulates the increased synthesis of lipids and lipoproteins. If serum $\pi$ does indeed regulate lipogenesis, it does so quite independently of any effect on albumin metabolism.

Our findings indicate that albumin plays no essential role in maintaining a normal rate of lipid removal and are consistent with the hypothesis that one component of nephrotic hyperlipidemia, reduced removal of lipids from blood, results from the urinary loss of a liporegulatory substance in the urine; and that this substance is not albumin. Furthermore, although reduced serum $\pi$ may directly stimulate the synthesis of lipids or of lipoproteins by mechanisms yet to be elucidated, there is no relationship between augmented albumin synthesis and hyperlipidemia. In addition, these data strongly suggest that the reduced clearance of CM and VLDL is not related to reduced postheparin LPL activity in nephrotic rats.

\section{Acknowledgments}

The authors are indebted to Professor Sumi Nagase from the Department of Chemistry, Sasaki Institute, Chiyoda-ku, Tokyo (Japan) for providing us with a breeding colony of analbuminemic rats as a gift and to Dr. Hidekazu Tsukamoto for invaluable assistance in maintenance of the rat colony.

This work was supported in part by the research service of the Department of Veterans Affairs and by grants from the Northern California Kidney Foundation and from the Dean's Research Fund for the University of California Davis School of Medicine. 


\section{References}

1. Staprans, I., C. D. Anderson, F. W. Lurz, and J. M. Felts. 1980. Separation of a lipoprotein lipase cofactor from the alpha-acid glycoprotein fraction from urine of nephrotic patients. Biochim. Biophys. Acta. 617:514-523.

2. Staprans, I., J. M. Felts, and W. G. Couser. 1987. Glycosaminoglycans and chylomicron metabolism in control and nephrotic rats. Metab. Clin. Exp. 36:496-501.

3. Chan, M. K., J. W. Persaud, L. Ramdial, Z. Varghese, P. Sweny, and J. F. Moorhead. 1981. Hyperlipidemia in untreated nephrotic syndrome, increased production or decreased removal? Clin. Chim. Acta. 117:317-323.

4. Marsh, J. B. 1984. Lipoprotein metabolism in experimental nephrosis. J. Lipid. Res. 25:1619-1623.

5. Radding, C. M., and D. Steinberg. 1960. Studies on the synthesis and secretion of serum lipoproteins by rat liver slices. J. Clin. Invest. 39:1560-1569.

6. Marsh, J. B., and D. L. Drabkin. 1960. Experimental reconstruction of metabolic pattern of lipid nephrosis: key role of hepatic protein synthesis in hyperlipemia. Metab. Clin. Exp. 9:946-955.

7. Soothill, J. A., and R. M. Kark. 1956. The effects of infusions of salt-poor human serum albumin on serum cholesterol cholinesterase, and albumin levels in healthy subjects and in patients ill with the nephrotic syndrome. Clin. Res. Proc. 4:140-141.

8. Jones, A. L., N. B. Ruderman, and M. G. Herrera. 1967. Electron microscopic and biochemical study of lipoprotein synthesis in the isolated perfused rat liver. J. Lipid Res. 8:429-446.

9. Esumi, H., Y. Takahashi, T. Sekiya, S. Sata, S. Nagase, and T. Sugimura. 1982. Presence of albumin mRNA precursors in nuclei of analbuminemic rat liver lacking cytoplasmic albumin mRNA. Proc. Natl. Acad. Sci. USA. 79:734-738.

10. Nagase, S., K. Shimamune, and S. Shumiya. 1980. Albumindeficient rat mutant: an animal model for analbuminemia. Exp. Anim. 29:33-38.

11. Esumi, H., S. Sato, M. Okui, T. Sugimura, and S. Nagase. 1979. Turnover of serum proteins in rats with analbuminemia. Biochem. Biophys. Res. Commun. 87:1191-1199.

12. Nagase, S., and K. Shimamune. 1979. Albumin-deficient rat mutant. Science (Wash. DC) 205:590-591.

13. Takahashi, M., K. Kusumi, S. Shumiya, and S. Nagase. 1983. Plasma lipid concentrations and enzyme activities in Nagase analbuminemia rats (NAR). Exp. Anim. 32:39-46.

14. Ando, S., K. Kon, Y. Tanaka, S. Nagase, and Y. J. Nagai. 1980. Characterization of hyperlipidemia in Nagase Analbuminemia Rat (NAR). Biochemistry 87:1859-1892.

15. Kikuchi, H., S. Tamura, S. Nagase, and S. Tsuiki. 1983. Hypertriacylglycerolemia and adipose tissue lipoprotein lipase activity in the nagase analbuminemic rat. Biochim. Biophys. Acta. 744:165-170.

16. Kaysen, G. A., W. G. Kirkpatrick, and W. G. Couser. 1984 Albumin homeostasis in the nephrotic rat: nutritional considerations. Am. J. Physiol. 247:(Renal Fluid Electrolyte Physiol. 16):F192-F202.
17. Hutchison, F. N., M. Schambelan, and G. A. Kaysen. 1987. Modulation of albuminuria by dietary protein and converting enzyme inhibition. Am. J. Physiol. 253:(Renal Fluid Electrolyte Physiol. 22):F719-F725.

18. Kaysen, G. A., H. Jones, Jr., V. Martin, and F. N. Hutchison. 1989. A low protein diet restricts albumin synthesis in nephrotic rats. J. Clin. Invest. 83:1623-1629.

19. Bollman, J. L., J. L. Cain, and J. A. Grindlay. 1948. Techniques for the collection of lymph from the liver, small intestine or thoracic duct of the rat. J. Lab. Clin. Med. 33:1349-1352.

20. Trout, D. L., E. H. Estes, Jr., and S. J. Freidberg. 1960. Titration of free fatty acids of plasma: A study of current methods and a new modification. J. Lipid Res. 1:199-202.

21. Bar-on H., Y. I. Chen, and G. M. Reaven. 1981. Evidence for a new cause of defective plasma removal of very low density lipoproteins in insulin-deficient rats. Diabetes. 30:496-499.

22. Havel, R. J., H. Eder, and J. H. Bragdon. 1955. The distribution and chemical composition of ultracentrifugally separated lipoproteins of human serum. J. Clin. Invest. 34:1345-1353.

23. Whayne, T. F., Jr., and J. M. Felts. 1970. Activation of lipoprotein lipase: Effects of rat serum lipoprotein fractions and heparin. Circ. Res. 27:941-951.

24. Laurell, C. B. 1972. Electroimmunoassay. Scand. J. Clin. Lab. Invest. 29(Suppl. 124):21-23.

25. Kaysen, G. A., and J. B. Watson. 1982. Mechanism of hypoalbuminemia in the $7 / 8$ nephrectomized rat with chronic renal failure. Am. J. Physiol. 243:(Renal Fluid Electrolyte Physiol. 12):F372-F378.

26. Lowry, O. H., N. J. Rosebrough, A. L. Farr, and R. J. Randall. 1951. Protein measurement with the Folin phenol reagent. J. Biol. Chem. 193:265-275.

27. Allain, C. A., L. S. Poon, C. S. G. Chan, W. Richmond, and P. C. Fu. 1974. Enzymatic determination of total serum cholesterol. Clin. Chem. 20:470.

28. Fossati, P., and L. Prencipe. 1982. Serum triglycerides determined colorimetrically with an enzyme that produces hydrogen peroxide. Clin. Chem. 28:2077.

29. McGowan, M. W., J. D. Artiss, D. R. Strandbergh, and B. Zak. 1983. A peroxidase-coupled method for the colorimetric determination of serum triglycerides. Clin. Chem. 29:538.

30. Aukland, K., and H. M. Johnsen. 1974. A colloid osmometer for small fluid samples. Acta Physiol. Scand. 90:485-490.

31. Matthews, D. E., and W. Farewell. 1985. Using and Understanding Medical Statistics. Karger, New York. 123 pp.

32. Edelstein, D., C. Arbeeny, and J. R. Chowdhury. 1987. Effect of albumin and dextran on the hyperlipidemia in analbuminemic rats. Arteriosclerosis. 7(5):535a. (Abstr.)

33. Allen, J. C., J. H. Baxter, and H. C. Goodman. 1961. Effects of dextran, polyvinylpyrrolidone and gamma globulin on the hyperlipidemia of experimental nephrosis. J. Clin. Invest. 40:499-508.

34. Kaysen, G. A., J. Gambertoglio, J. M. Felts, and F. N. Hutchison. 1987. Albumin synthesis, albuminuria and hyperlipemia in nephrotic patients. Kidney Int. 31:1368-1376. 